\title{
MODELLING AND SIMULATION OF SOLAR PHOTOVOLTAIC SYSTEM AND INTERFACING WITH CLOSED LOOP BOOST CONVERTER AND NEUTRAL POINT CLAMPED MULTILEVEL INVERTER
}

\author{
Rahul Prasad, Suresh Gawre, Nikhil Kumar \\ Maulana Azad National Institute of Technology, Bhopal MP
}

\begin{abstract}
In the power generation sector, Natural Resources like Solar, Wind, Tidal, Geothermal, Hydro etc have always played a very important role. Out of these solar PV (photo voltaic) is most popular due to its significant advantages. Controlling the output of solar PV system and harmonics at the load end are key aspects. The main theme of this paper is to control output of solar PV system with the help of PI controller and reduction of harmonics at the load end by using Neutral Point Clamped Multilevel Inverter. In this paper, commercial solar arrays of $1.2 \mathrm{~kW}$ along with close loop boost converter have been interfaced with neutral point clamped multilevel inverter. In this paper mathematical model of $P V$ system have been presented and the characteristic of $p v$ cell have been verified experimentally with the help of solar simulator under varying climate and load condition. Also, design and simulation of a Boost converter which works in continuous conduction mode (CCM) using Solar PV array voltage as input has been done. $P V$ model has been interfaced with Multilevel inverter (MLI) and the results for three level, five level, seven level, nine level and eleven level are presented. Models have been developed for different level of inverter in MATLAB to achieve this purpose.
\end{abstract}

\section{Keywords}

solar PV array, close loop boost converter, PI controller, Neutral point clamped multilevel Inverter

\section{Introduction}

Renewable energy source demand is increasing day by day as it is ecofriendly and pollution free. The increasing demand of total energy consumption has pushed more effort to produce more electricity to meet the demand. Out of all renewable energy sources solar energy has been emerged as one of the best source of energy supplier, as solar energy is clean, green,

DOI : 10.14810/elelij.2015.4408 
environmental friendly and inexhaustible. Grid connected and standalone systems are the two major utility in solar system.

The PV system has the ability to convert the incident sun light into direct current electricity. However the voltage generated by one cell is low which cannot be used for any consumer load. So, for achieving high voltage many cells should be connected in series and for achieving reasonable current cells should be connected in parallel. The main objective of paper is to use the full available potential of the renewable energy source i.e. Solar Energy to generate electricity for giving power to the low power single phase industrial loads or domestic loads. Generally Solar panels are designed in such a manner to have output voltage of about 23-38 $\mathrm{V}$ at maximum power point (MPP) and rated power around $160 \mathrm{~W}$ at a radiation level of $1000 \mathrm{~W} / \mathrm{m} 2$.

In the next stage solar panels are connected to DC-DC converter. In this stage the maximum power can be tracked with the help of maximum power point algorithm and the output can be kept synchronized with loads [1]. Generally boost converters are used which increases the generated solar panels voltage.

The output voltage of Solar PV array is very much sensitive to solar irradiation and temperature hence to make a proper balance during sudden changes in the input of boost converter, a closed loop control of boost converter designed by "voltage mode control" method with PI controller is used. Maximum power point algorithm or Power-Voltage (P-V) or Voltage Current (V-I) or any characteristic of PV solar panel can be obtained using solar simulator [9]. These characteristics will be required to decide what will be the numbers of cells required to be connected in series or parallel as per the assigned load. In the next step inverter is used to convert the DC in to an AC. In this paper Neutral Clamped Inverter topology have been adopted. This helps to reduce total harmonic distortion (THD). Also this results in increase deficiency and reliability.

The proposed system model basically has three parts, they are:

1. Solar Photovoltaic Array

2. DC-DC Boost Converter with PI control loop

3. Single-Phase Neutral Point Clamped MLI

\section{Modelling of PV System}

PV arrays can be built with the help of series and parallel combination of solar cells. An ideal Solar cell is modeled by a current source in parallel with a diode in case of double exponential model i.e. Monocrystalline PV cell. 


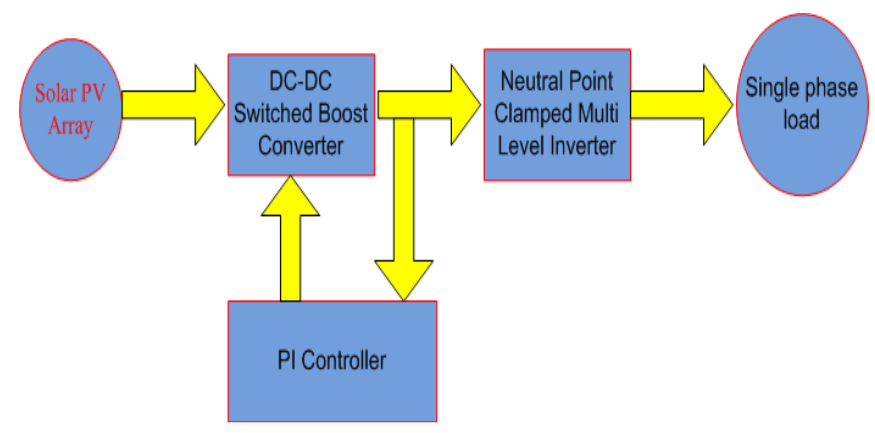

Fig. 1. The block diagram of the proposed work

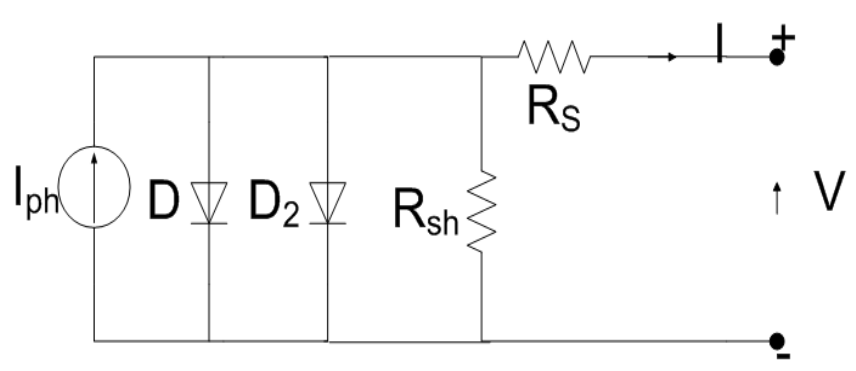

Fig. 2. Electrical equivalent circuit of a PV cell

The output current of PV cell depends photon current that can be also determined by load current depending upon the solar insolation during its operation equation.

$\mathrm{I}=\mathrm{I} \_$ph-I_0 $\left[\exp \left(\left(\mathrm{V}+\mathrm{R} \_\mathrm{s} \mathrm{I}\right) /\left(\mathrm{N} 『 \times \mathrm{V} \rrbracket \_\mathrm{T}\right)\right)-1\right]-\mathrm{I} \_02\left[\exp \left(\left(\mathrm{V}+\mathrm{R} \_\mathrm{s} \mathrm{I}\right) /\left(\mathrm{N} \_2 \llbracket \times \mathrm{V} \rrbracket \_\mathrm{T}\right)\right)-1\right]-$ $\left(\mathrm{V}+\mathrm{R} \_\right.$s I $) / \mathrm{R} \_$sh

Where:

e: Electron charge $(1.602 \times \llbracket 10 \rrbracket \wedge(-19) \mathrm{C})$, $\mathrm{k}$ :Boltzmann constant,

I: Cell output current, A, Iph: Photon generated current, Io: Reverse saturation current for diode D, Io2: Reverse saturation current for diode D2, Rs: Series resistance of cell, Rsh: Shunt resistance of cell, V: Cell output voltage, $\mathrm{VT}:$ Thermal voltage $=\mathrm{VT}=(\mathrm{Ns} * \mathrm{~N} * \mathrm{k} * \mathrm{~T}) / \mathrm{q}$, $\mathrm{T}$ : cell operating temperature, 
q: Charge on an electron,

$\mathrm{N}$ :Diode emission coefficient or quality factor of the diode $\mathrm{D}$,

N2:Diode emission coefficient or quality factor of the diode D2.

PV panel output is dependent on solar insolation and temperature. The modeling of PV panel has been done by using two diode model and one simulator has been employed for the study of and IV (Current versusVoltage) and PV (Power versus Voltage) characteristic under various environmental condition. An experiment has been conducted with the help of solar simulator designed and developed by Western Regional Instrumentation Centre, University of Mumbai and IIT bombay shown in fig. 3 .

By the help of solar simulator different characteristic of solar cell can obtained like IV characteristic and PV characteristic for different insolation, for different operating temperature.

The specification of solar cell used in solar simulator is given in table I .

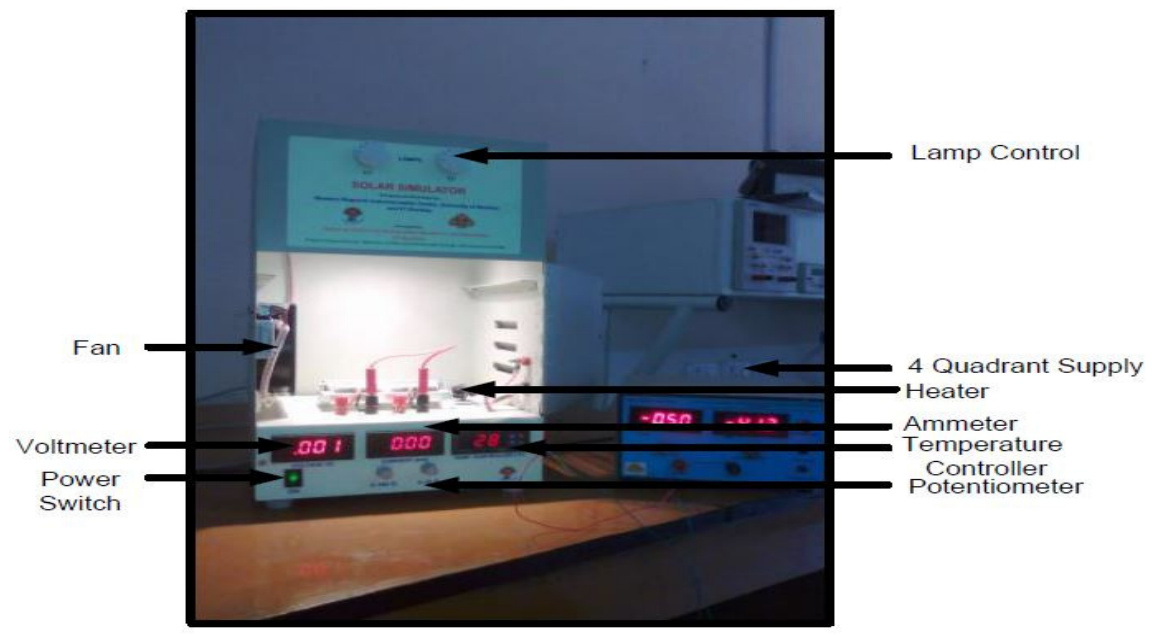

Fig. 3. Solar simulator

TABLE 1. TEST CONDITIONS

\begin{tabular}{|c|c|}
\hline \multicolumn{2}{|c|}{ Standard test Condition: Insolation $\mathbf{1 0 0 0} \mathbf{~ W / \mathbf { m } ^ { 2 }}$ at $\mathbf{2 5}^{\mathbf{0}} \mathbf{C}$} \\
\hline $\mathrm{V}_{\mathrm{oc}}$ & $600 \mathrm{mV}$ \\
\hline $\mathrm{I}_{\mathrm{sc}}$ & $490 \mathrm{~mA}$ \\
\hline Solar cell area & $16 \mathrm{~cm}^{2}$ \\
\hline
\end{tabular}


Electrical and Electronics Engineering: An International Journal (ELELIJ) Vol 4, No 4, November 2015

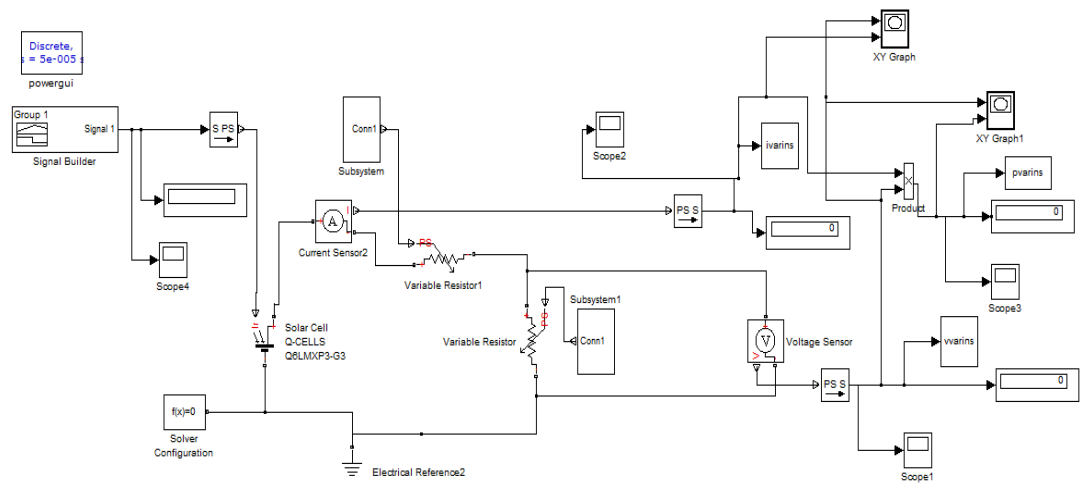

Fig. 4. MATLAB Model of Solar Cell in SimScape Library

Rating and specification used in simulation model of solar photovoltaic array are as below:

TABLE 2. PV PANEL PARAMETERS

\begin{tabular}{|l|l|}
\hline Module Type & SANIOHIP225HDE1 \\
\hline No of cells per Module & 60 \\
\hline No of series connected Module/string & 1 \\
\hline No of parallel string & 5 \\
\hline
\end{tabular}

TABLE 3.RATING AND SPECIFICATION USED IN SIMULATION MODEL OF SOLAR PHOTOVOLTAIC ARRAY

\begin{tabular}{|l|l|}
\hline Parameters & Rating \\
\hline$N_{s}$ & 60 \\
\hline$N_{p}$ & 5 \\
\hline$V_{O c}$ & $41.79 \mathrm{~V}$ \\
\hline$I_{s c}$ & $7.13 \mathrm{Amp}$ \\
\hline$V_{m p p}$ & $33.9 \mathrm{~V}$ \\
\hline$I_{m p p}$ & $6.63 \mathrm{Amp}$ \\
\hline$R_{s}$ & $0.02 \mathrm{Ohm}$ \\
\hline$I_{p h}$ & $7.15 \mathrm{Amp}$ \\
\hline$T_{r}$ & $25^{\circ} \mathrm{C}$ \\
\hline$S$ & $1000 \mathrm{w} / \mathrm{cm}^{2}$ \\
\hline$I_{D}$ & 0.002 \\
\hline$I_{s a t}$ & $3.149 \mathrm{e}^{-8}$ \\
\hline & \\
\hline
\end{tabular}


Electrical and Electronics Engineering: An International Journal (ELELIJ) Vol 4, No 4, November 2015

Fig.5 shows the IV and PV characteristic of solar cell which is also verified by the experiment on solar simulator

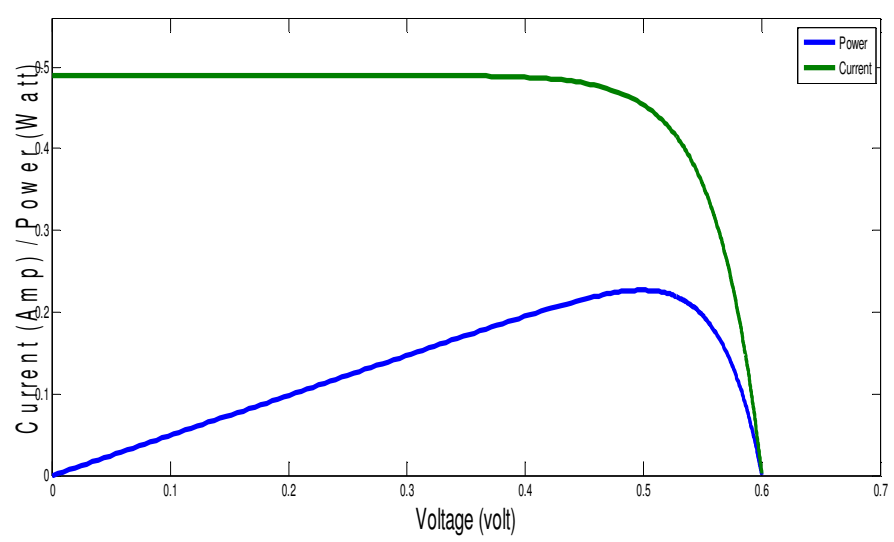

Fig. 5. PV And IV Characteristic Of Solar Cell

Fig.6 shows IV Characteristic of Solar Cell with different insolation at 250C

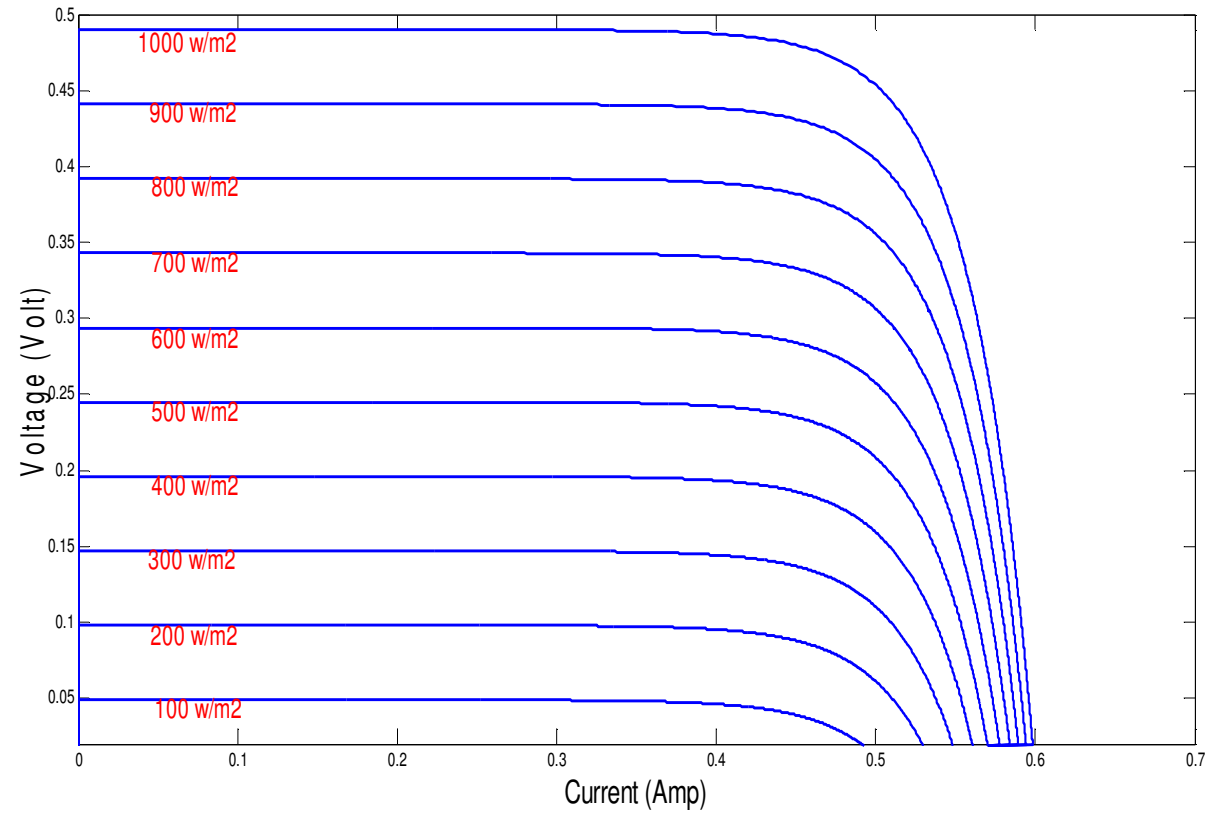

Fig. 6. IV Characteristic of Solar cell Under Different Insolation 
Electrical and Electronics Engineering: An International Journal (ELELIJ) Vol 4, No 4, November 2015

Fig. 7 shows PV Characteristic of Solar Cell with different insolation at 250C

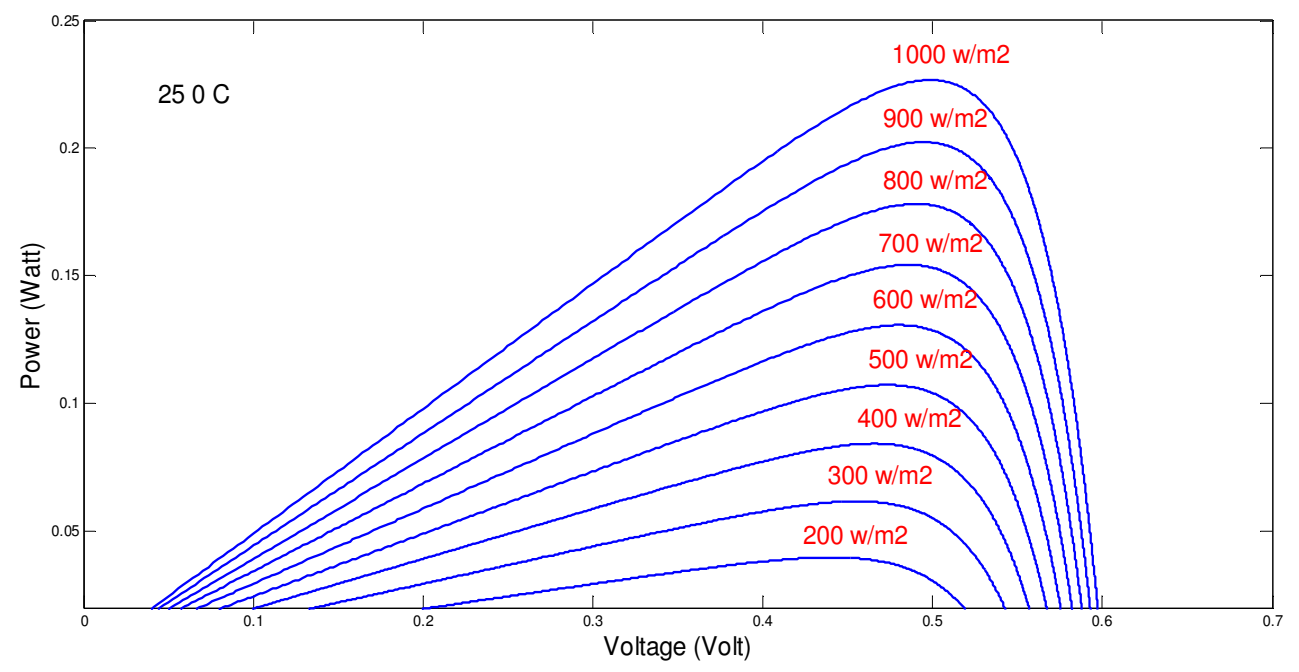

Fig. 7. PV Characteristic of Solar cell Under Different Insolation

Fig. 8 shows IV Characteristic of Solar Cell with $1000 \mathrm{~W} / \mathrm{m} 2$ insolation at temperature equals to $00 \mathrm{C}, 300 \mathrm{C}$ and $600 \mathrm{C}$

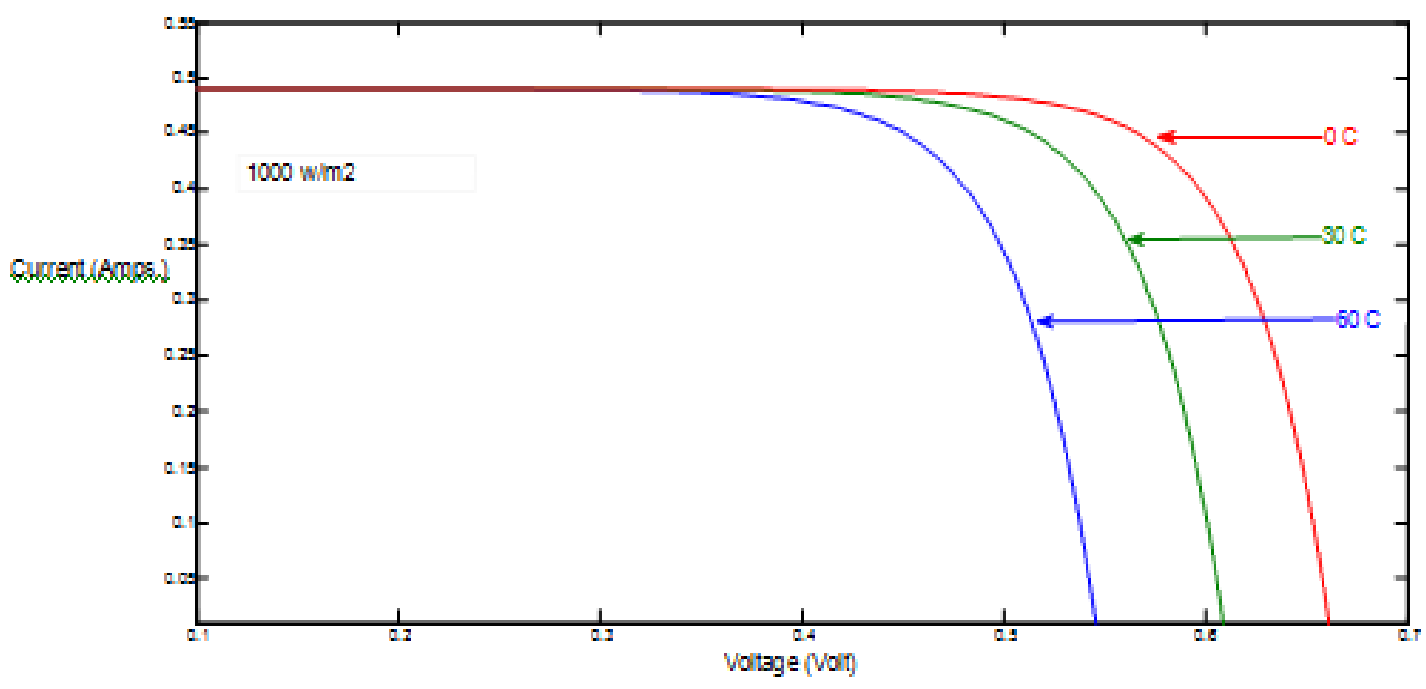

Fig. 8. PV Characteristic of Solar cell Under Different Temperature 
Fig. 9 shows PV Characteristic of Solar Cell with $1000 \mathrm{~W} / \mathrm{m} 2$ insolation at temperature equals to 00C, 300C and 600C and constant solar insolation i.e $1000 \mathrm{w} / \mathrm{m} 2$.

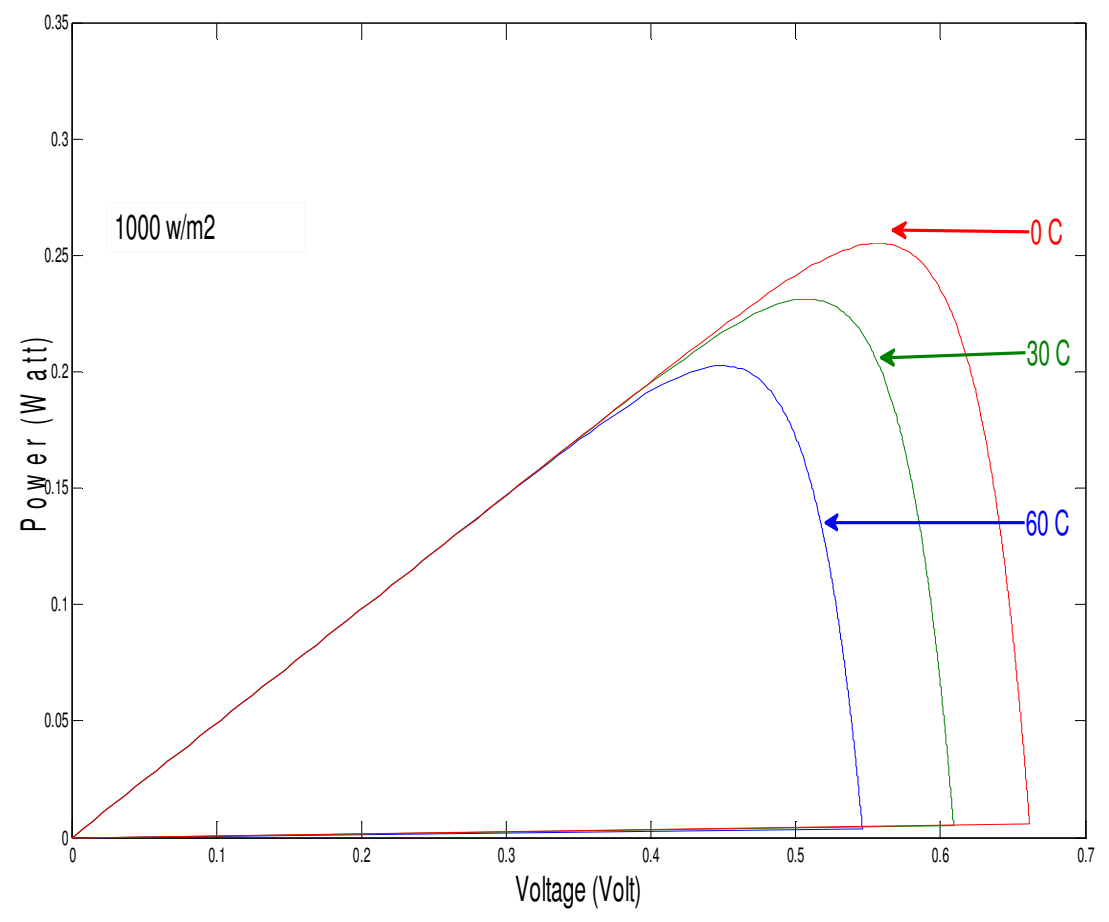

Fig. 9. PV Characteristic of Solar cell Under Different Temperatures

The volatge of the cell decreses as the temperature increases proportionaly and short circuit current will be decreasing logrithmically.

As from the IV Characteristic, solar cell can be modeled as Current source because about $70-80 \%$ of its characteristic is similar to that of current source of DC type. Hence for the AC load the output of the cell (or pannel) should be inverted that can be done by either conventional two level inverter or by multilevel inverter. Here in this paper DC to AC convertion is done by Nutral point clamped multilevel inverter.

\section{Modeling of Conventional DC-DC Boost Converter}

In a DC-DC Boost converter, the average output voltage Vo is greater than the input voltage Vi. It steps up an unregulated source voltage $\mathrm{Vi}$ to a desired regulated load voltage Vo. Boost Converter mainly consists of one inductor and two switches (usually a transistor switch and a diode) as shown in fig. below. 
Electrical and Electronics Engineering: An International Journal (ELELIJ) Vol 4, No 4, November 2015

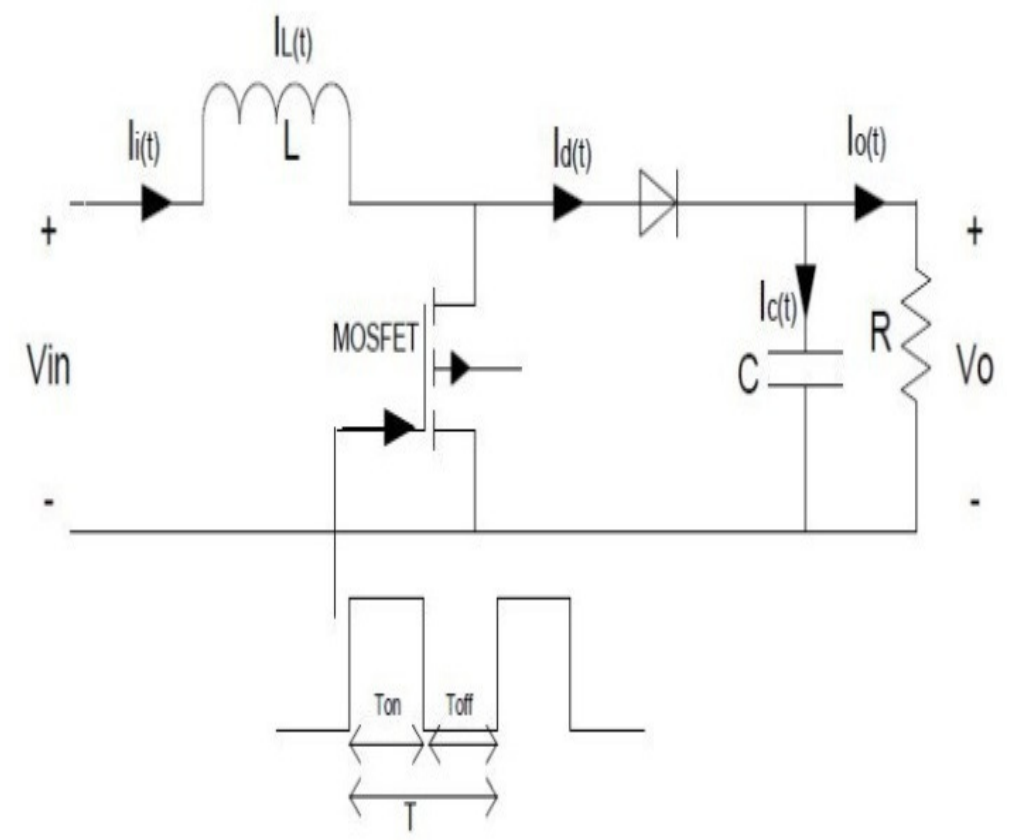

Fig. 10. Circuit Diagram of boost converter

The output voltage of boost converter is given by:

$$
v_{o}=\frac{v_{\text {in }}}{(1-k)}
$$

Where, $\mathrm{k}=$ duty ratio of and is given by:

$$
k=\frac{t_{\text {on }}}{T}
$$


For continuous conduction mode of operation, the value of inductor and filter capacitor should be greater than the critical value i.e. $\mathrm{L}>\mathrm{Lc}$ and $\mathrm{C}>\mathrm{Cc}$ which is given by:

$$
\begin{gathered}
L=\frac{v_{\text {in }} \times\left(v_{\text {out }}-v_{\text {in }}\right)}{\Delta I_{L} \times F_{S} \times V_{\text {out }}} \\
C_{\text {out }}=\frac{I_{\text {out }(\max )} \times D}{F_{s} \times \Delta V_{\text {out }}}
\end{gathered}
$$

\section{Design of PI Controller for Boost Converter}

A PI Controller (proportional-integral controller) is a feedback controller which drives the plant to be controlled with a weighted sum of the error (difference between the output and desired value) and the integral of that value. Mainly PI controller is used to improve the performance of the system under major disturbances and improves the response of whole system [2]. The dynamic performance of the PI controller can be improved by giving feedback to the controller to overcome the disturbances and ripple in the output of converter. Here we are using Voltage mode control. In this, the actual voltage is compared with reference value. The block diagram is as shown in fig 11.

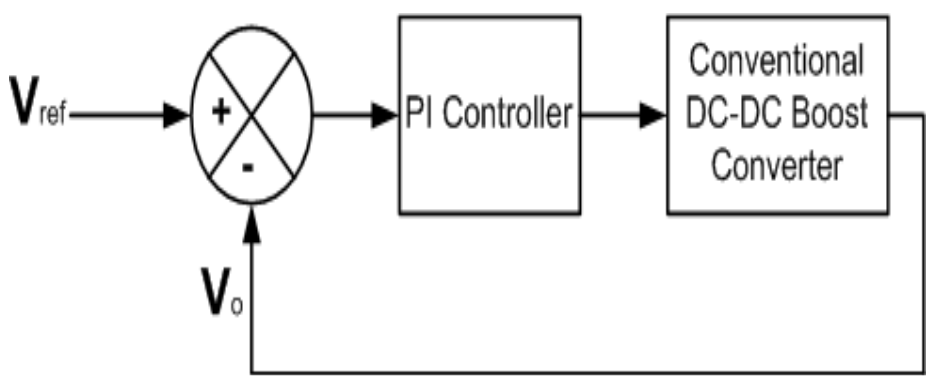

Fig. 11. Block diagram of boost Converter 
There are several methods for tuning of controller parameters i.e. Kp and Ki like the Good Gain Method and the Ziegler-Nichols Method. Simulink Model for Close Loop Boost Converter fed with PV array is shown below:

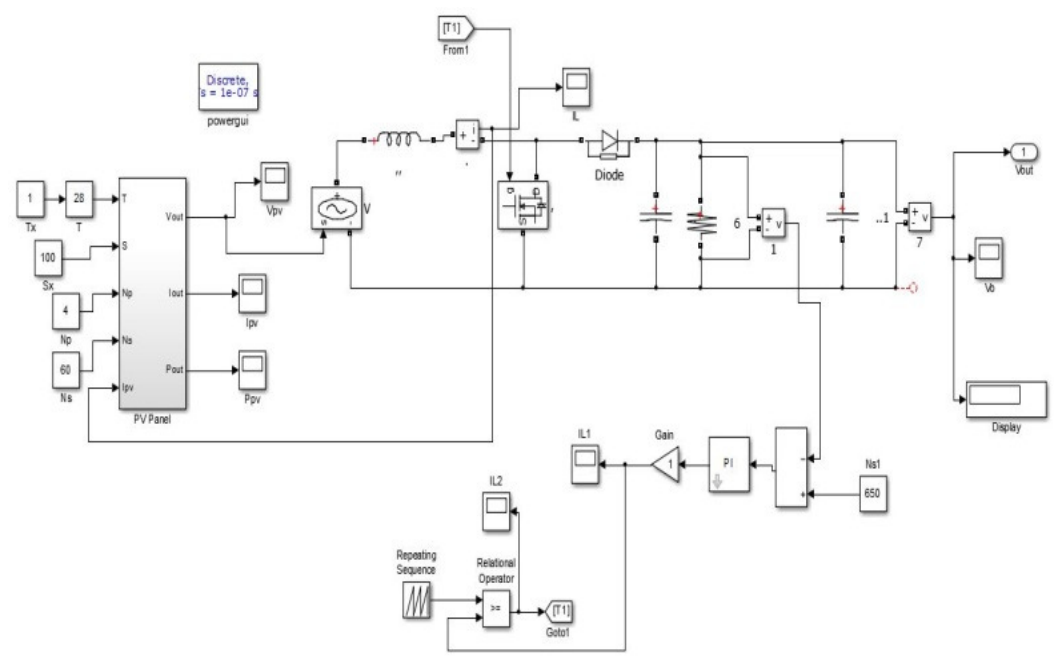

Fig. 12. Simulink Model for Close Loop Boost Converter

Rating and specification used in simulation model of solar dc-dc boost converter are as below:

TABLE 4. RATING AND SPECIFICATION USED IN SIMULATION MODEL OF SOLAR DC-DC BOOST CONVERTER

\begin{tabular}{|l|l|}
\hline Parameters & Ratings \\
\hline$F_{s}$ & $100 \mathrm{KHz}$ \\
\hline$V_{s}$ & $25 \mathrm{~V}$ \\
\hline$V_{o}$ & $650 \mathrm{~V}$ \\
\hline$D$ & 0.916 \\
\hline$L$ & $8.013 \times 10^{-4} \mathrm{H}$ \\
\hline$C$ & $3.14 \times 10^{-4} \mathrm{~F}$ \\
\hline$K_{p}$ & 0.006 \\
\hline$K_{i}$ & 0.0009 \\
\hline
\end{tabular}

\section{Interfacing of Solar Cell with Neutral Point Clamped Multilevel Inverter}

In this paper we have done the simulation for three, five, seven, nine and eleven level Multilevel inverter and have shown the result. The below figure, fig. 12, shows the interfacing between PV 
pannel and Nutral Point Clamped Multilevel Inverter (NPCMLI) for three level inverter. The output of inverter contains three level shown in fig. 13. This circuit has several advantages like it helps to reduce the voltage stress on each power device due to the utilization of multiple levels on the DC bus. It also offers Reduced total harmonic distortion (THD) [3]. Because solar cell given

in the SIMSCAP library of MATLAB that's why it gives output in the form of physical signal. To convert physical signal into the simulink signal 'physical signal to simulink converter' is used which convert physical signal into unitless simulink signal.

Values of the parameters used in simulation model of single-phase neutral point clamped multi level inverter are as below:

TABLE 5. VALUES OF THE PARAMETERS USED IN SIMULATION MODEL OF SINGLE-PHASE NPCMLI

\begin{tabular}{|l|l|}
\hline Parameter & Ratings \\
\hline$f_{r}$ & $50 \mathrm{KHz}$ \\
\hline$f_{c}$ & $100 \mathrm{KHz}$ \\
\hline$m_{o}$ & 0.85 \\
\hline$V_{s}$ & $625 \mathrm{~V}$ \\
\hline
\end{tabular}

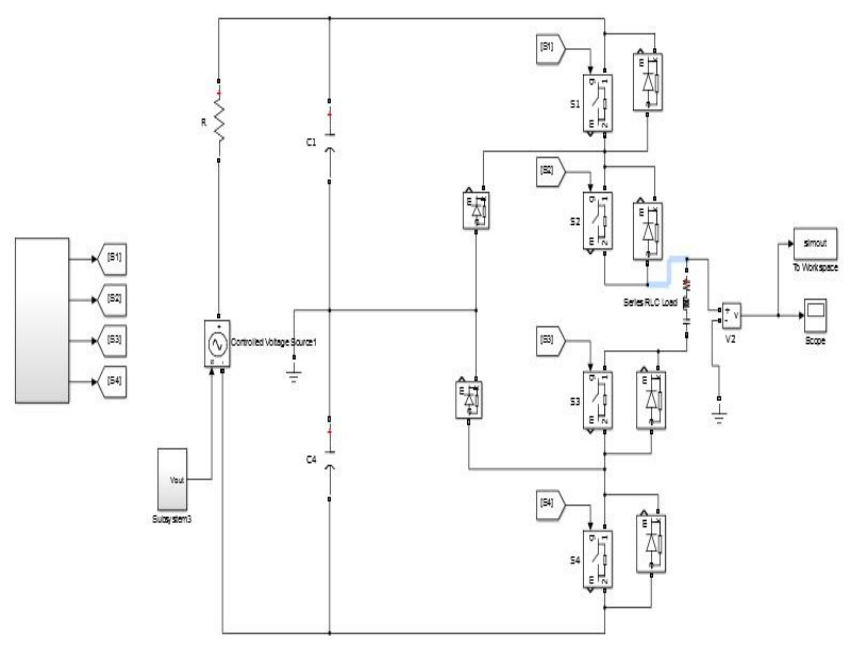

Fig. 13. Simulink Model for Single-phase NPCMLI with feeding Single-phase load 
For switching Sine Pulse Width Modulation Technique has been employed in which Phase Opposition Dispossion (POD) carrier scheme used.The output voltage waveforms and their Fast Fourier Transform analysis of output voltage for three, five and seven level are shown in fig. 24, $25,26,27$ and 28 respectively.

\section{Result and Conclusions}

The complete system is modeled and simulated in MATLAB-Simulink software under the favorable conditions and the results of the different parts of the system have been taken.

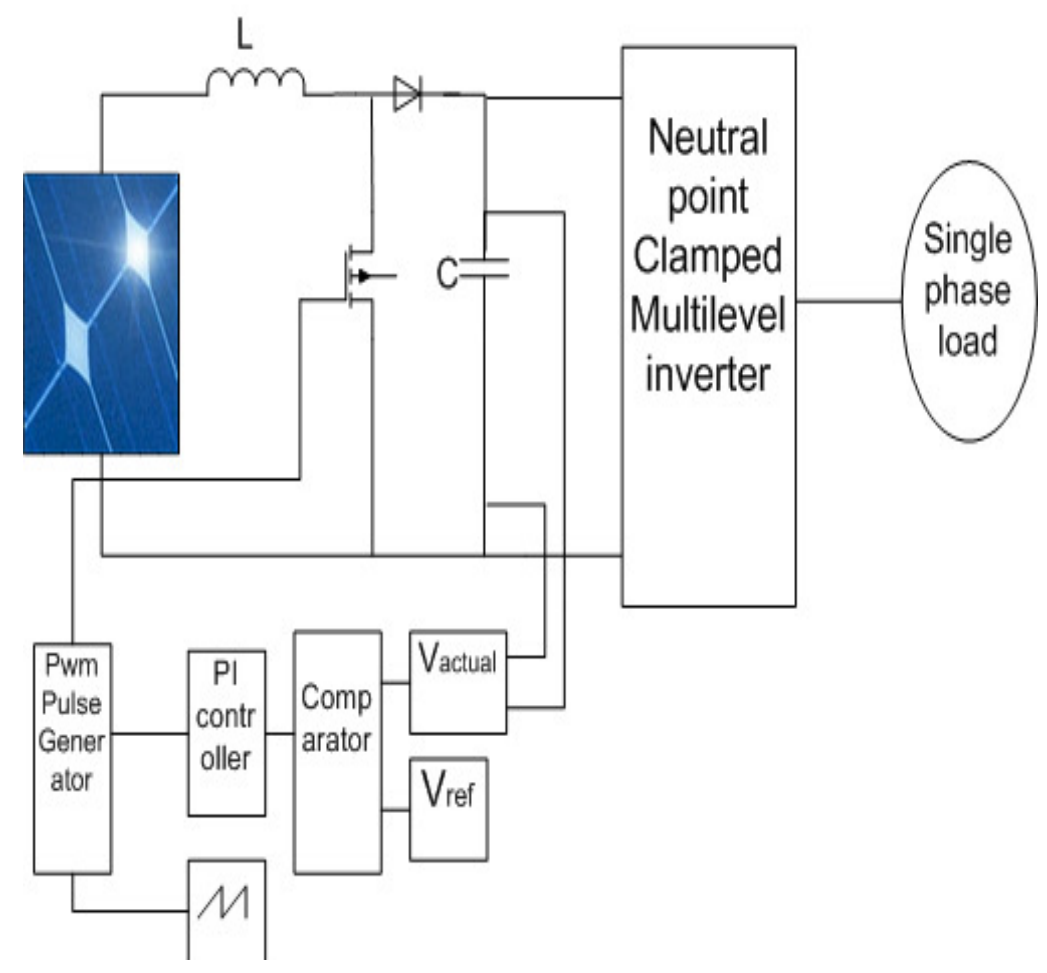

Fig. 14. Model of the Proposed Work

MATLAB-Model has been developed for getting the characteristics (i.e. I-V and P-V Curves) of Solar Photovoltaic array. The results of the various parts of the proposed system are shown below.

Conventional close loop boost converter has been used as the interface between solar photovoltaic array and MLI to increase the voltage level, generated by solar photovoltaic array. By the use of closed loop control of boost converter, the disturbances at the input side of the 
Electrical and Electronics Engineering: An International Journal (ELELIJ) Vol 4, No 4, November 2015

converter can be balanced easily and successful operation of the system has been done. This increases the efficiency of the conversion.

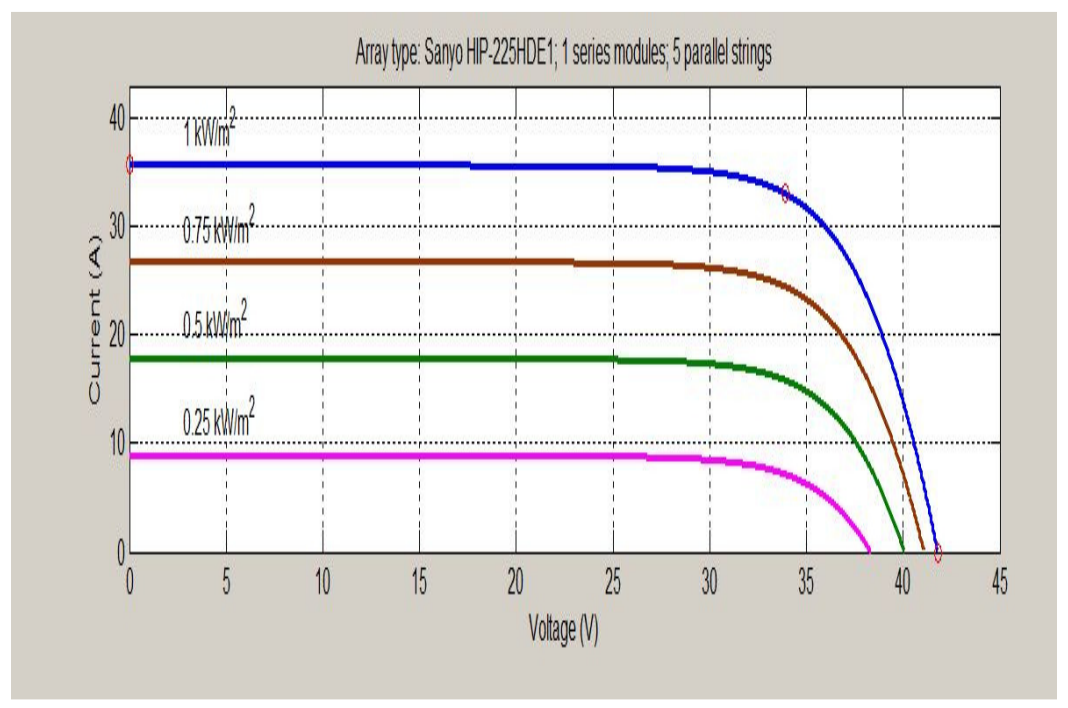

Fig. 15. I-V Characteristics of Solar Photovoltaic Array Sanyo HIP-225HDE1

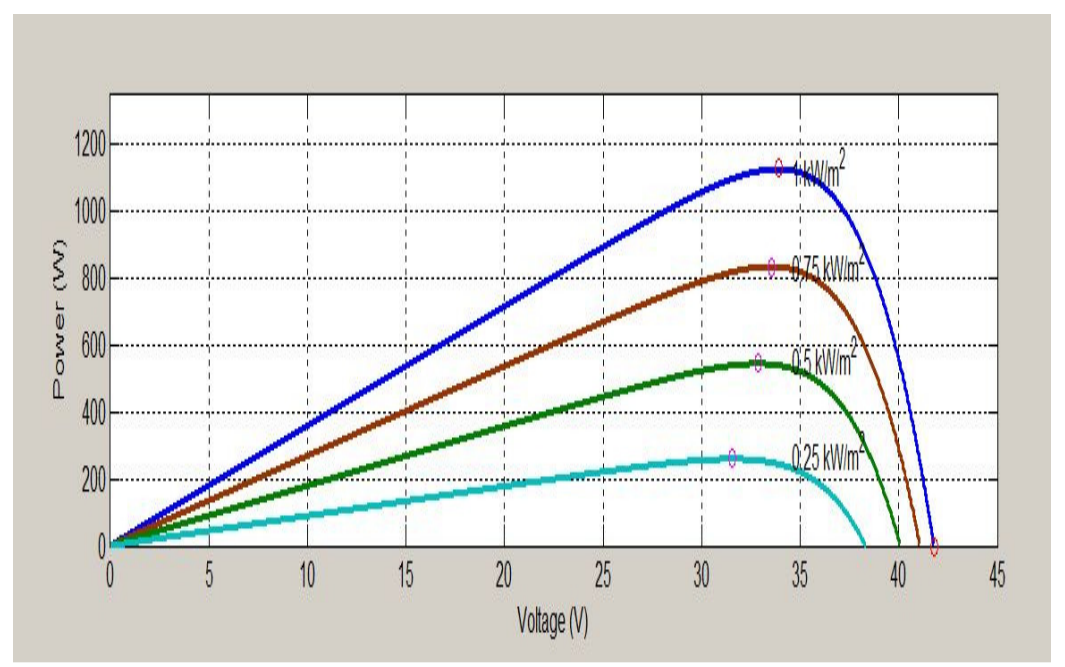

Fig. 16. P-V Characteristics of Solar Photovoltaic Array Sanyo HIP-225HDE1 
Electrical and Electronics Engineering: An International Journal (ELELIJ) Vol 4, No 4, November 2015

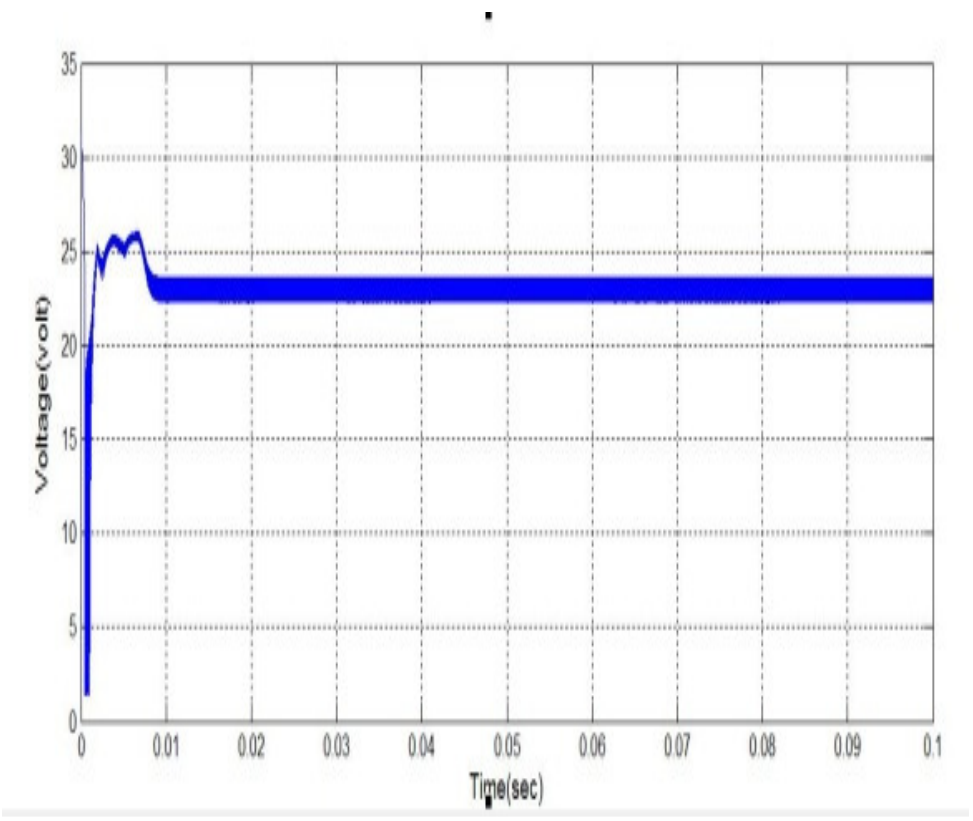

Figure 17. Solar PV array output voltage

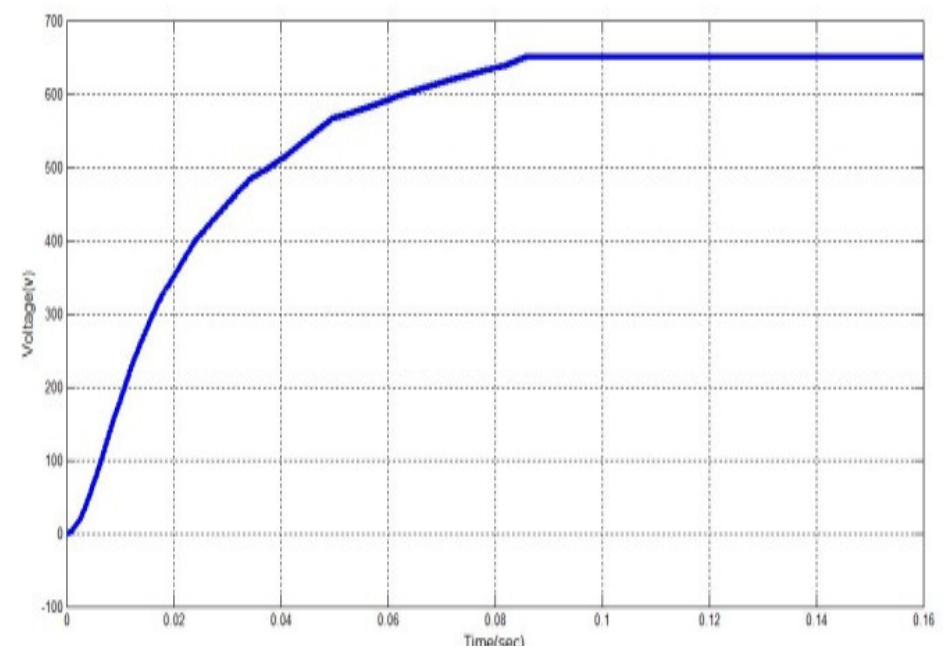

Fig. 18. Boosted Output Voltage of Solar Photovoltaic Array under Different Irradiation 
Electrical and Electronics Engineering: An International Journal (ELELIJ) Vol 4, No 4, November 2015

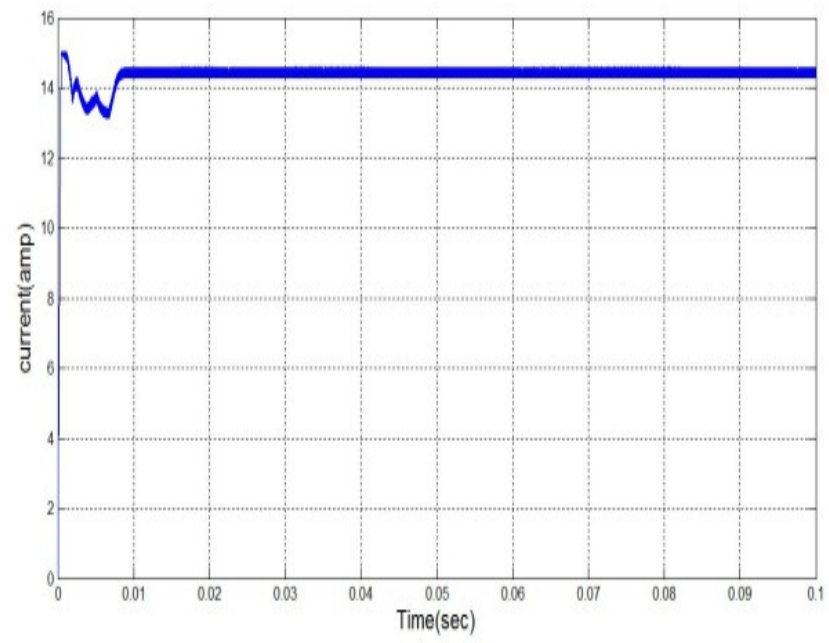

Fig. 19. Inductor Current of Boost Converter in Continuous Conduction Mode

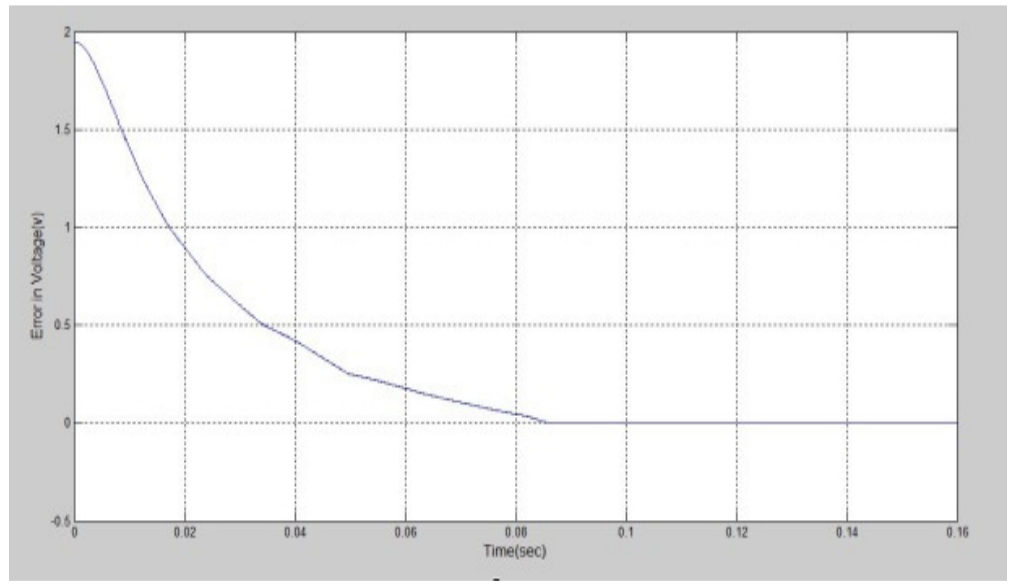

Fig. 20. Output of PI Controller

This NPCMLI topology helps reduce the total THD, harmonics, switching losses. It also lowers the ratings for switches. Reduction in THD reduces size and cost of filter. Also quality of voltage and current waveform improves as the level increases. 
Electrical and Electronics Engineering: An International Journal (ELELIJ) Vol 4, No 4, November 2015

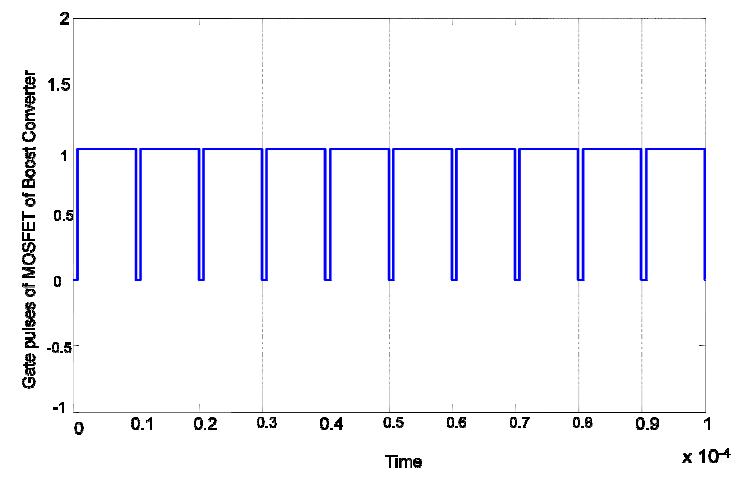

Fig. 21. Switching pulses of MOSFET generated by PWM

Application of Power electronics (Boost converter and NPCMLI) with renewable energy sources (Solar PV Array) increases efficiency of the system \& overcome the following drawbacks of systems having renewable energy sources alone:

1. Higher cost of Filter.

2. Uncontrollability.

3. Difficulties in Operation.

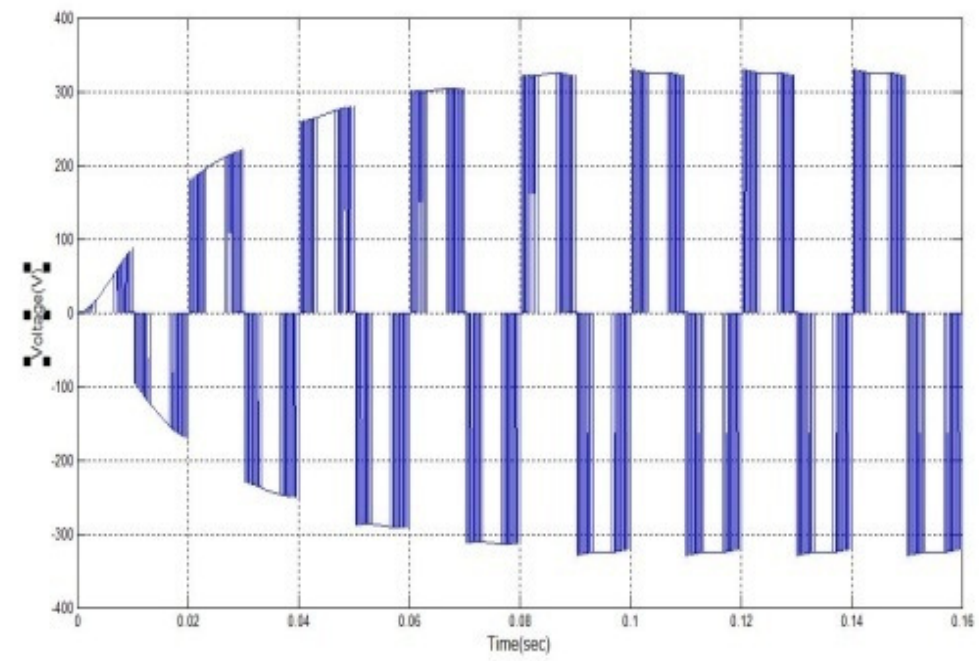

Fig. 22. Level Output Voltage of NPCMLI 
Electrical and Electronics Engineering: An International Journal (ELELIJ) Vol 4, No 4, November 2015

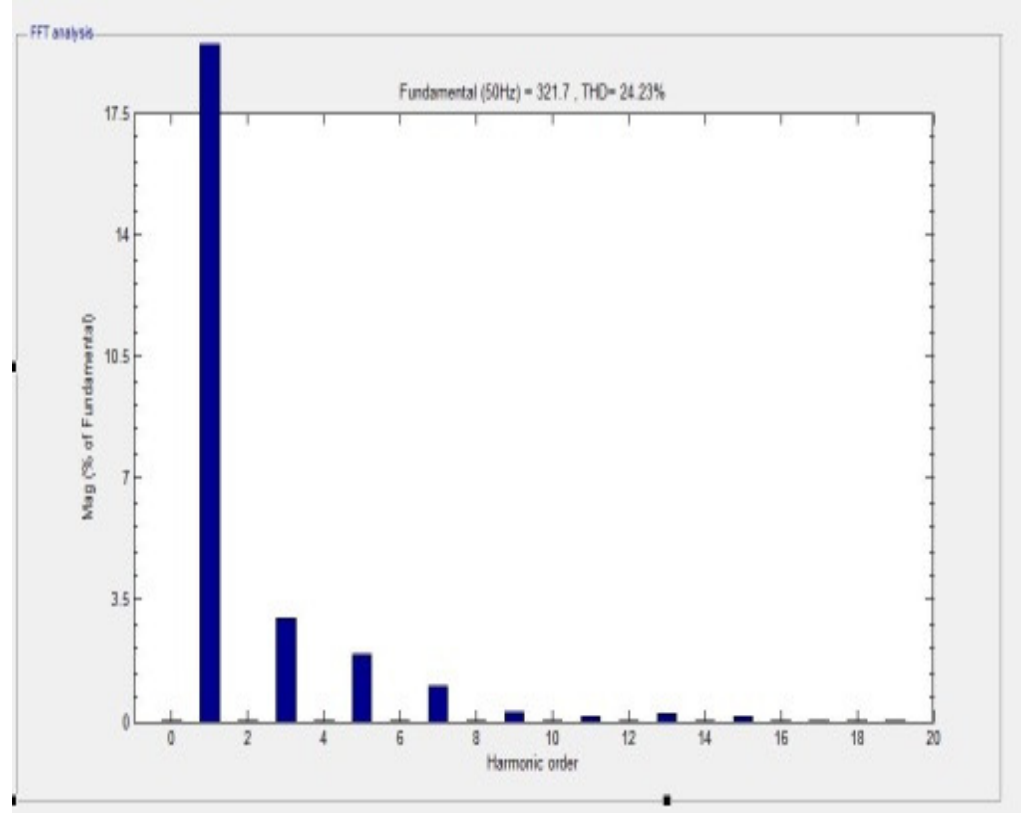

Fig. 23. FFT Analysis of 3 Level Output Voltage of NPCMLI

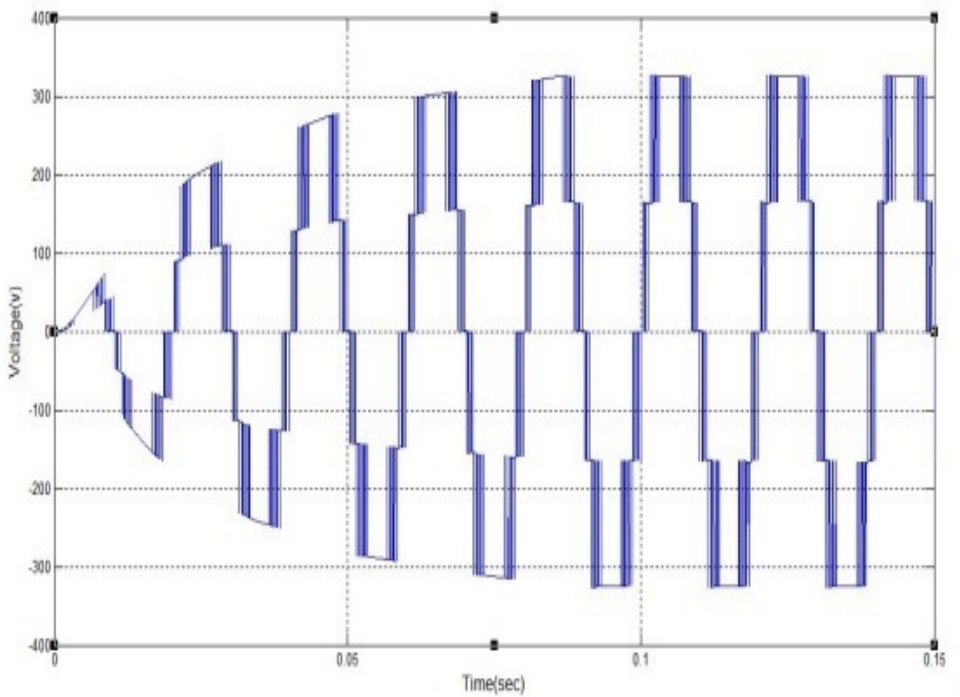

Fig. 24. Level Output Voltage of NPCMLI 
Electrical and Electronics Engineering: An International Journal (ELELIJ) Vol 4, No 4, November 2015

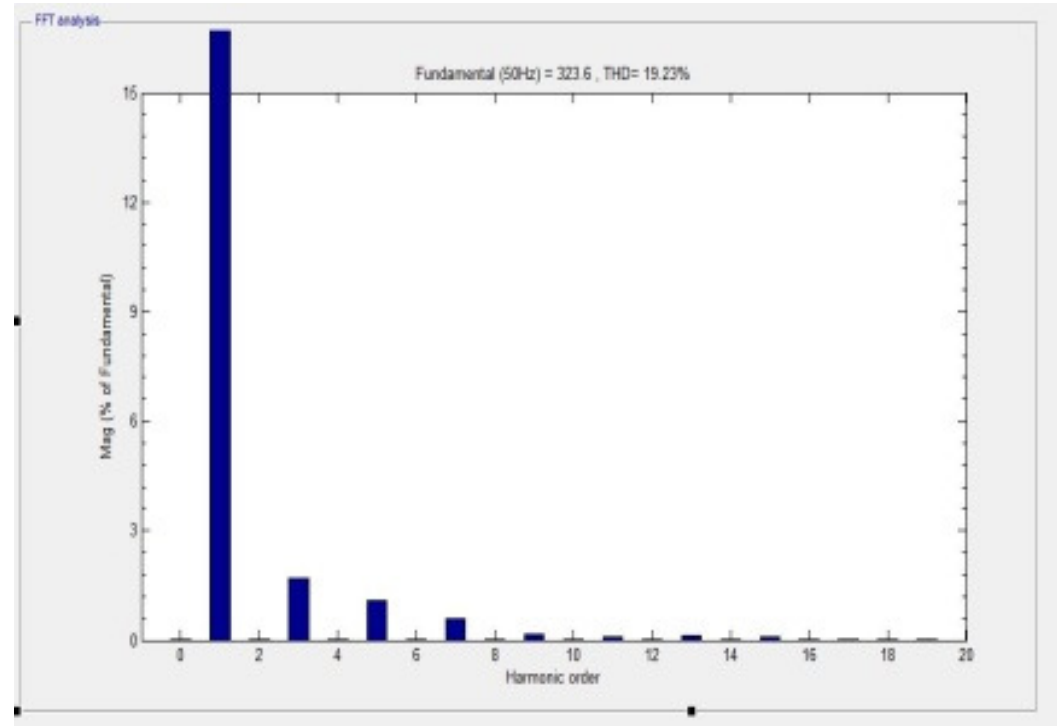

Fig. 25. FFT Analysis of 5 Level Output Voltage of NPCMLI

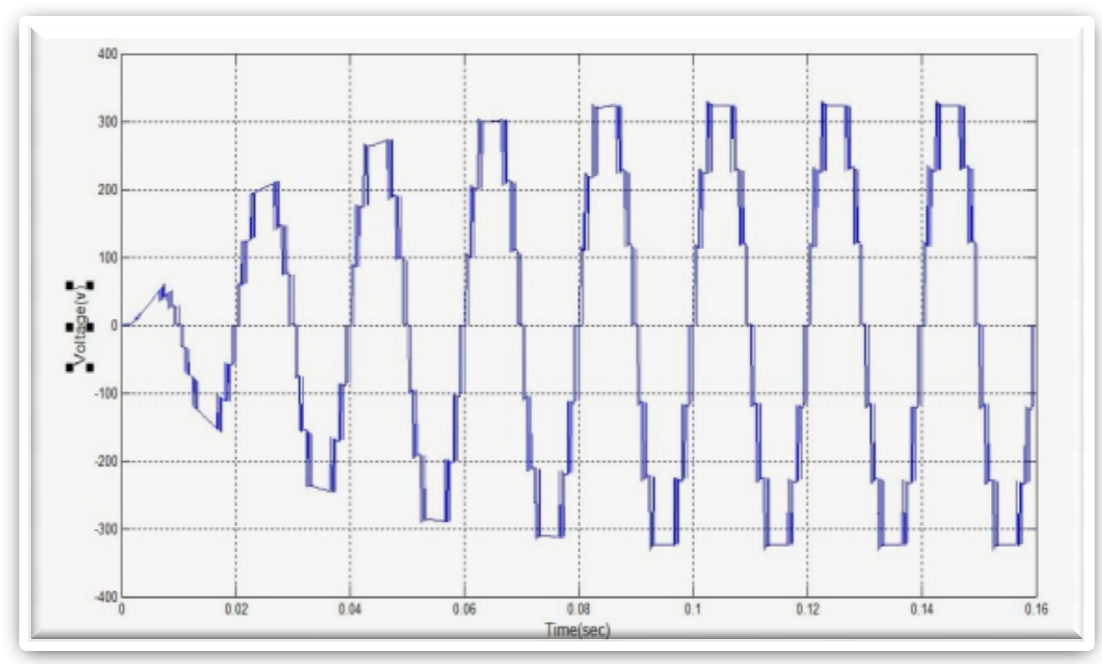

Fig. 26. Level Output Voltage Of NPCMLI 
Electrical and Electronics Engineering: An International Journal (ELELIJ) Vol 4, No 4, November 2015

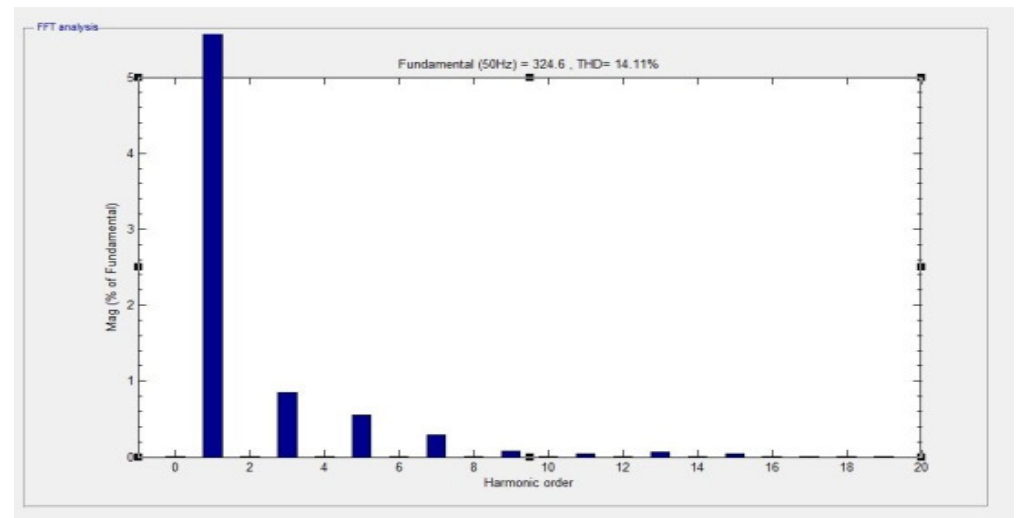

Fig. 27. FFT Analysis of 7 Level Output Voltage Of NPCMLI

In the following fig. 26 comparison is done in THD in output voltage for different levels of NPCMLI. And we can clearly see that as the number of levels increases the THD in the output voltage decreases.

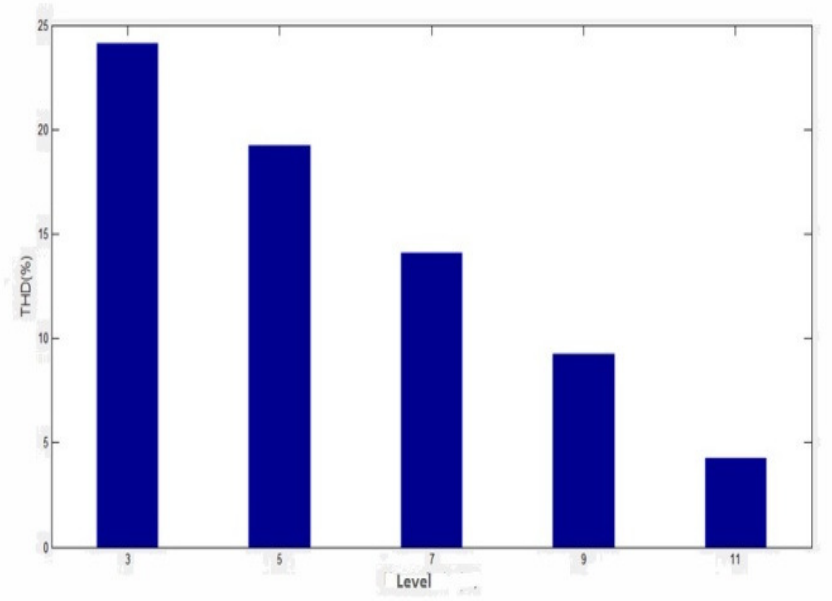

Fig. 28. Comparison Of THD with Different

So, the THD in case of 11 level NPCMLI is less than 5\% which is suitable according to the IEEE standards 519-1992 Harmonic Limits [15] which restricts THD to 5\% for 69KV and below bus voltage. 
Electrical and Electronics Engineering: An International Journal (ELELIJ) Vol 4, No 4, November 2015

\section{References}

[1] A. Chitra,S.Himavathi"Modeling and Experimental validation of Solar PVsystem for Cascade HBridge Multilevel Inverter",International Conference on Power, Energy and Control (ICPEC).pp. 260265,2013.R.G.G. Raju, N.P Subramaniam, "Operation and modeling of photovoltaic power generators",IEEE CONFERENCE on Recent Advances in Space Technology Services and Climate Change (RSTSCC)VOL. 55, NO. 7, pp. 466- 469, 2010.

[2] J. Rodriguez, S. Bernet, P.K. Steimer, I.E Lizama, “A Survey on Neutral-Point-Clamped Inverters Volume: 57Issue: 7, pp. 2219- 2230, 2010.

[3] Jih-Sheng Lai, Fang ZhengPeng, "Multilevel inverters: a survey of topologies, controls, and applications" IEEE Transaction on Industrial electronics, Volume:49 pp. 724- 738 , 2002.

F. Bouchafaa, D. Beriber, M.S Boucherit,"Modeling and control of a gird connected PV generation system” IEEE Transaction on Industrial electronics ,pp 315- 320, 2010.

[4] M. Kaliamoorthy, R.M. Sekar, R. Rajaram, "A new single-phase PV fed five-level inverter topology connected to the grid” IEEE International Conference on Communication Control and Computing Technologies (ICCCCT) ,pp. 196- 203, 2010.

[5] L. G. Franquelo, J. Rodriguez, J. I. Leon, S. Kouko, R. Portillo, and M. A. M. Prats, "The age of multilevel converters arrives," IEEE Ind.Electron. Mag., vol. 2, no. 2, pp. 28-39, Jun. 2008.

[6] J. Kwon, et al. "Photovoltaic Power Conditioning System With Line Connection", IEEE Transactions on Industrial Electronics, vol. 53, no. 5, pp. 1048-1054, 2006.

[7] R. Gules, J. D. P. Pacheco, H. L. Hey, J. Imhoff, “A maximum power point tracking system with parallel connection for PV stand-alone applications,” IEEE Trans. Ind. Electron., Vol. 55, No. 7, Jul 2008.

[8] Y. H. Lim and D. C. Hamill, "Synthesis, simulation and experimental verification of a maximum power point tracker from nonlinear dynamics", IEEE 32nd Annual Power Electronics Specialist Conf.(PESC), Jun. 2001

[9] E. I and O. Rivera, "Maximum Power Point Tracking using the Optimal Duty Ratio for DC-DC Converters and Load Matching in Photovoltaic Applications," IEEE, pp. 987-991, 2008.

[10] Nikhil Kumar, Suresh Gawre, Deepak Verma and Tushar Kumar, "Physical Design and Modeling of 24v/48v Dc-Dc Boost Converter for Solar PV Application by Using Simscape Library in Matlab", International Journal of applied control, electrical and electronics Engineering (IJACEEE) Vol 2 No 2, May ,2014

[11] Mahmud, N.; Sozer, Y.; Husain, I., "Energy capture improvement of a solar PV system using a multilevel inverter," Energy Conversion Congress and Exposition (ECCE), 2011 IEEE , vol., no., pp.3933,3940, 17-22 Sept. 2014

[12] Shimi, S.L.; Thakur, T.; Kumar, J.; Chatterji, S.; Karanjkar, D., "MPPT based solar powered cascade multilevel inverter," Emerging Research Areas and 2013 International Conference on Microelectronics, Communications and Renewable Energy (AICERA/ICMiCR), 2013 Annual International Conference on , vol., no., pp.1,5, 4-6 June 2013

[13] Blooming, T.M.; Carnovale, D.J., "Application of IEEE STD 519-1992 Harmonic Limits," Pulp and Paper Industry Technical Conference, 2006. Conference Record of Annual , vol., no., pp.1,9, 18-23 June 2006 